Jurnal Olahraga \& Kesehatan Indonesia

Volume 1 Nomor 1 (2020)

E-ISSN: 2747-061X

available online at https://jurnal.stokbinaguna.ac.id/index.php/jok

\title{
PENGARUH WORKOUT FROM HOME PADA MASA PANDEMI TERHADAP PENINGKATAN HIPERTROFI OTOT
}

\author{
Antonius Tri Wibowo ${ }^{1} *$, Asna Syafitri Sari ${ }^{2}$, Arfian Fani Purilawa ${ }^{3}$ \\ ${ }^{123}$ Universitas Mercu Buana Yogyakarta, DIY, Indonesia, 55753 \\ *Coressponding Author: antoniustriwibowo@mercubuana-yogya.ac.id
}

\section{Keterangan}

Rekam Jejak:

Received, Oktober 2020

Revised, November 2020

Accepted, Desember 2020

Kata Kunci:

Workout From Home, Masa Pandemi, Hipertrofi Otot

Pandemi Covid-19 mengakibatkan terjadinya perubahan pada semua bidang kehidupan di masyarakat, karena pemerintah pusat dan pemerintah daerah mengeluarkan peraturan pembatasan berkumpul baik itu di lingkungan sekolah, kerja, dan sarana umum lainnya guna menghindari penyebaran Pandemi Covid-19 tersebut. Para pecinta olahraga beban yang biasanya dapat dengan mudah melakukan latihan bebas di tempat gym, kini jadi tidak bisa melakukannya. Gym lover sebutan bagi pecinta olahraga latihan beban tentunya akan mengalami kesulitan sehingga diperlukan bentuk latihan mandiri untuk tetap menjadag kebugaran dan untuk meningkatkan masa ototnya. Dari penelitian ini para mahasiswa yang berjumlah 31 orang melakukan sebuah program latihan workout from home selama 3 bulan dengan frekuensi latihan dalam 3 kali dalam seminggu. Hasil penelitian ini menunjukkan adanya perbedaan rata-rata lingkar dada yang signifikan sebelum dan sesudah penerapan WFH sebesar 77,39 dan 80,16. Perbedaan rata-rata lingkar lengan yang signifikan sebelum dan sesudah penerapan WFH yaitu sebesar 28,13 dan 29,68, dan kemudian hasil untuk lingkar paha terdapat perbedaan rata-rata sebelum dan sesudah penerapan WFH sebesar 50,39 dan 52,33 .
\end{abstract}




\section{PENDAHULUAN}

Dunia sedang mengalami Pandemi Covid-19 yang memberikan dampak pada semua segi kehidupan manusia meliputi sosial, kesehatan, budaya, politik dan ekonomi. Semua Negara di dunia sedang berpikir keras untuk menghadapi situasi yang tidak biasa karena memaksa sebuah Negara untuk mengambil tindakan untuk melindungi warga negaranya dari penularan virus Covid-19 ini yang sudah menyebabkan korban manusia hampir mendekati 4,85 juta orang positif terpapar, 321.818 kasus kematian dan 216 negara di Dunia terdampak Pandemi Covid-19 ini (WHO, 2020). Kasus di Negara Indonesia penderita yang dikonfirmasi berjumlah 20.162 positif, sedangkan yang meninggal dunia 1.278 dan yang sudah mengalami kesembuhan berjumlah 4.838, untuk di dalam negeri kasus merata di beberapa kota besar di wilayah pulau Jawa seperti di Daerah Istimewa Jakarta dengan 6.301 kasus positif, Jawa timur 2.998 positif, Jawa Barat berjumlah 1.962 positif, Jawa tengah berjumlah 1.217 kasus positif dan beberapa kota besar di luar pulau Jawa adalah Sulawesi Selatan yang merupakan kasus terabnyak berjumlah 1.135 kasus positif, Sumatra Barat berjumlah 674 selain itu beberapa kota besar di luar jawa ada Nusa Tenggara Barat, Kalimantan Selatan, Bali dan Papua terdeteksi di atas 400 pederita yang positif. Untuk Wilayah Daerah Istimewa Yogyakarta sendiri mencapai 215 kasus positif dan 105 mengalami kesembuhan dan meninggal berjumlah 8 (Kemenkes, 2020).

Menurut data dari WHO pada awalnya virus ini muncul di dunia dari Negara China tepatnya di kota Wuhan, Tiongkok, ditemukannya pada akhir bulan Desember 2019 (WHO, 2020). Menurut WHO infeksi COVID-19 ini jika manusia terifeksi maka akan timbul gejala ringan, sedng, berat, gejala klinis utama yang muncul yaitu deman (suhu $>380 \mathrm{C}$ ), batuk dan kesulitan bernafas. Selain itu dapat disertai dengan sesadak memberat, fatigue, myalgia, gejala gastrointestinai seperti diare dan gejala saluran nafas lain (Yuliana, 2020). Dari beberapa literature berkaitan media kesehatan Virus jenis ini sangat cepat dalam penularanya yaitu bisa melalui droplet dari penderita dan massuk dalam tubuh manusia melalui melalui mulut dan hidung. Beberapa usaha yang dilakukan dan menjadi saran dari pemerintah melalui Juru Bicara Satgas penanggulangan COVID-19 bapak Achmad Yurianto dibeberapa kesempatan dalam konferensi pers, mengatakan bahawa masyarakat dihimbau untuk membiasakan jaga kebersihan diri, mencuci tangan dengan sabun, mengenakan masker, menghindari kerumunan dan tidak keluar rumah kecuali jika perlu sehingga masyarakat luas menyebutnya dengan Work From Home (BBC Indonesia, 2020).

Berbagai usaha yang dilakukan oleh pemerintah dalam memutus rantai penyebaran Covid-19 ini sehingga memunculkan beberapa peraturan yang memaksa untuk beberapa lembaga, perusaahaan, kampus, sekolah, tempat hiburan dan beberapa tempat umum lain diminta untuk meliburkan diri dan melakukan work from Home(WFH), semua pekerjaan dan semua kegiatan diharapakan dilakukan dari rumah. Dalam situasi WFH ini banyak orang mengeluhkan berbagai respon yang muncul dari masyarakat, bosen dan menjadi stress adalah beberapa yang hal yang dihadapai masyarakat. Pada penekanan untuk selalu melakukan social distancing dan melakukan kegiatan di dalam rumah dengan mengerjakan pekerjaan berjam-jam di depan computer membuat nyeri otot dan meningkatkan stress lebih cepat (Dipna Videlia Putsanra, 2020). Para ahli psikologi dari Harvard Medical School Inna Khazna menyarankan dalam kondisi melakukan WFH sering melakukan pereganan otot dan di temabh berjalan dan bermeditasi selama 15-30 menit, selain itu para ahli kesehatan dan olahraga menyarankan untuk melakukan olahraga beban seperti push up, lunges, squat ataupun dengan memanfaatkan peratalatn yang ada di dalam rumah (Dipna Videlia Putsanra, 2020).

Bagi para penyuka olahraga angkat beban kalau dalam kondisi normal melakukan latihan biasanya melakukan di dalam gym atau pusat kebugaran, dalam kondisi untuk mencegah penularan maka aturan pemerintah pusat dan perturan daerah meminta semua masyarakat untuk melakukan work form home dan menutup tempat umum. Dengan adanya aturan dari pemerintah dan kesadaran dari pemilik tempat gym untuk mengurangi penularan covid maka tempat 
kebugaran ditutup sehingga para penyuka latihan beban tidak bisa melakukan olahraga di gym, sehingga membuat mereka mengurangi melakukan olahraga. Menurut para ahli sebenarnya melakukan olahraga di rumah diharuskan karena dalam situassi yang mengaharuskan masyarakt untuk selalu berada di rumah sampai waktu tidak menentu selesainya Pandemi ini akan membuat kebosanan dan membuat orang cenderung kearah stress sehingga berampak pada imunitasnya. Para dokter spesialis olahraga menyarankan melakukan olahraga atau aktivitas fisik intensitas sedang selama work from home sehinggga akan menaikan imun tubuh, ada beberapa latihan yang bisa dilakukan seperti olahraga aerobic dan olahraga kekuatan otot seperti push up, squat, lunges dan beberapa variasi gerakan yang berfokus ke penekanan kekuatan otot (Afrilia Suryanis, 2020).

Untuk mengoptimalkan perkembangan otot diperlukan latihan yang cenderung kearah latihan beban, sehingga diharapkan dengan latihan beban, otot akan menghadapi tahanan terhadap beban. Latihan beban sendiri merupakan suatu bentuk latihan yang menggunakan media alat beban untuk menunjang proses latihan dengan tujuan untuk meningkatkan kebugaran, kekuatan otot, kecepatan, pengencangan otot, hypertrophy otot, rehabilitasi, maupun penambahan dan pengurangan beratbadan (Djoko Pekik I, 2000). Latihan beban merupakan salah satu macam latihan tahanan secara isotonis, yang paling sering digunakan dalam olahraga. Latihan beban adalah latihan-latihan yang sistematis dimana beban hanya dipakai sebagai alat untuk menambah kekuatan otot guna mencapai berbagai tujuan tertentu, misalnya memperbaiki kondisi fisik sedangkan tujuan latihan tahanan secara umum menurut ACSM (The American College of Sport and Medicine) meliputi kekuatan otot, daya tahan otot, hypertrophy otot, dan power otot.

Para penyuka olahraga latihan beban atau pelatih tentu akan mencari banyak cara untuk membuat otot yang dilatihnya menjadi optimal. Metode dalam latihan beban yang dapat digunakan untuk menyusun dan merangcang program latihan antara lain: Metode Super set,Set Blok/Set System, Circuit Training, Piramid Set, Drop Set dan masih banyak lagi meteode latihannya(Ade rai et al., 2007). Husein et al. (2007: 60) mengatakan bahwa, metode piramid merupakan salah satu sistem latihan kekuatan yang dipandang memiliki efek paling baik dalam peningkatan kekuatan. Pada sistem ini atlet mengangkat beban dari intensitas yang lebih rendah dengan ulangan banyak kemudian secara berangsur menuju ke intensitas yang lebih tinggi dengan ulangan sedikit.

Latihan beban dengan metode piramid sendiri adalah latihan dengan cara menaikan beban setelah selesai satu set, perlu diingat adalah beban awal adalah beban ringan $70 \%-80 \%$ yang ditentukan dari 1RM atlet baru akan meningkat bebannya dengan dikurangi repetisinya. Seiring dengan penambahan beban maka jumlah repetisi dikurangi (Ade rai et al., 2007). Menurut Sukadiyanto (Sukadiyanto, 2011) ada lima cara latihan kekuatan maksimal yang dapat ditempuh, yaitu dengan cara:(1) Menambah beban secara kontinyu, contoh beban latihan dari 70\%- 80\%-90\%-100\%.(2) Menambah beban secara bertahap, dari beban 70\%-70\%, 80\%-80\%, 90\%-90\%, 100\%-100\%. (3) Menambah beban secara bergelombang, dari beban $75 \%-80 \%$ 90\%-100\%-95\%-100\%-90\%. (4) Menambah dan mengurangi beban secara kontinyu, dari beban65\%-75\%-85\%-95\%-95\%-85\%-75\%-65\% (5) Cara piramid, dari beban 70\%-80\%-85\%90\%-95\%-100\%.

Dalam Latihan beban bisa dilakukan menggunakan alat bantu dan dilakukan di pusat kebugaran tetapi dalam kondisi Pandemi dan banyak lokasi dan tempat fasilitas umum ditutup sebagai antisipasi terjadinya penularan covid sehingga membuat orang melakukan olahraga di rumah yang biasanya disebut workout form home (WFH) karena melakukan latihan di rumah sendiri. Apa sebenarnya workout form home itu workout sendiri menurut penegertian dalam Bahasa inggris berarti kata benda atau kata sifat yang berarti melakukan sesi aktifitas atau lebih spesifik adalah melakukan sesi olahraga(Nurjaya, 2018). Secara umum workout from home adalah melakukan sesi Latihan olahraga di rumah dengan menggunakan peralatan yang tersedia di rumah. Pertanyaannya apakah Latihan di rumah sendiri ini bisa ada manfaatnya jika dibandingkan dengan Latihan di tempat kebugaran? mungkin bisa dibilang iya tapi juga tidak 
juga, karena asalkan melakukan Latihan dnegan benar dan panduan yang tepat tidak akan begitu jauh efektifitasnya bila dibandingkan dengan melakukan Latihan di pusat kebugaran.

Latihan olahraga sendiri di rumah sebenarnya malah menjadikan orang menjaddi kreatif dengan berpikir menggunakan apa dan bagaimana melakukannya sehingga bisa tertantang untuk selalu berpikir kreatif karena tidak seperti di tempat pusat kebugaran yang sudah tersedia alat dan bebannya. Ada abebrapa variasai dalam melakukan Latihan di rumah ini, sontoh melakukan push up, sit up, squat, burpes, dan beberapa Gerakan lainnya, sedangkan peralatan yang bisa di pergunakan adalah contoh sapu lantai, ember dan bisa memanfaatkan kursi untuk melakukan tricep deep (Realbuzz Team, 2020). Menjadi penting bagi orang yang melakukan Latihan di rumah adalah jangan lupa tetap melakukan warming up sebelum melakukan latihan dan melakukan cooling down setelah selesai latihan sehingga resiko cidera akan berkurang. Pemanasan.

Melakukan Work out from home akan menjadi menarik jika dilakukan dengan variasi gerakan yang bisa membuat otot kita tertantang untuk melakukan gerakan tersebut, selian itu kalori yang terbakar bisa akan sangat besar jika dilakukan kombinasi setlah melakukan Latihan beban dilanjtukan dengan Latihan kardio seperti jogging pelan di areal sekitar rumah ataupun menggunakan sepeda statis (Steve, 2020). Contoh program Latihan dalam satu sesi Jump rope, jumping jack, squat, lunges, hip extensions, hip rotation, sid leg swings dan push up, semua Gerakan itu dilakuakn sebanyak 10-20 repetisi dalam 3 set dengan recovery 2-4 menit. Setelah melakukan semua itu dilanjutkan dengan Latihan kardio maka kalori yang dikeluarkan akan relative sama dengan jika melakukan Latihan di pusat kebugaan (Matthews, 2014).

Hipertrofi otot adalah peningkatan ukuran dari sel-sel otot. Ini berbeda dari hiperplasia otot, yang adalah pembentukan sel-sel otot baru. Hipertrofi adalah pembesaran atau pertambahan massa total suatu otot(Pratama, 2012). Hipertropy ini terjadi dari akibat dari peningkatan jumlah filament aktin dan myosin dalam setiap serat otot, jadai menyebbkan pembesaran masing-masing serat otot, yang secara sederhana disebut hipertropy serat. Peristiwa sampai terjaddi hipertropy adalah efek dari respon otot terhaddap suatau kontraksi otot yang berlangsung pada kekuatan maksimal atau hampir maksimal 80\%b-90 \% Beban 1RM. Sehingga dengan adanya pembebanan pada otot akan membantu proses hipertopy tetntunya dengan selalu memegang prinsip latihan sehingga tidak terjadi cidera. Maka dari permasalahn di atas peneliti melakukan penelitian apakah dengan melakukan program latihan workout from home akan bisa meningkatkan hipertropi otot atau tidak.

\section{METODE}

Penelitian ini adalah penelitian eksperimen Pre Experimental Design dengan menggunakan pretest dan posttest design. Dari populasi 31 orang semuanya dijadikan sampel, sampel merupakan mahasiswa yang mengambil mata kuliah latihan beban di semester genap ini. Kemudian dilakukan pretest dengan pengambilan data awal mengukur lingkar dada, lingkar lengan (otot triceps dan biceps), lingkar perut ,dan berat badan (Sugiyono, 2010). Desain penelitian ini digambarkan ke dalam desain $\mathrm{O}_{1} \mathrm{X} \mathrm{O}_{2}$ keterangan $\mathrm{O}_{1}$ adalaah nilai prestest sebelum melakukan program latihan, dan $\mathrm{O}_{2}$ adalah nilai post test setelah sampel melakukan program latihan Work out From Home selama 3 bulan dari bulan April sampai Juni dengan jumlah 42 kali latihan (Creswell, 2013). Hipotesis diuji dengan one sample t-test Adapun intrumen latihan $W F H$ adalah bentuk latihan beban untuk kekuatan otot dengan memanfaatkan beban sendiri dan peralatan di dalam rumah, sampel akan melakukan latihan empat kali dalam seminggu sampai 3 bulan sehingga akan dilihat hasil perubahannya. Intrumen dalam $W F H$ yang digunakan dalam proses penelitian sebagai berikut:

Latihan 1 
- Latihan dada: Push Up Regular, Push Up Diamond, Incline Push Up, Decline Push Up, Push Up Wide.Latihan perut: Sit Up, V Sit Up,Crunch, Rusian Twist, Back Up, Side Bent Dumbel.

- Latihan biceps: Bicep Curl, Barbel Curl.

Latihan 2

- Latihan paha: Squat, Step Up Down, Front Lunges, Calf Raise, Riverse Raise, Wall Seat, Zigzag Lunges.

- Latihan triceps: Tricep Exetention, Tricep Deep, Tricep Kick Back.

Latihan 3

- Latihan bahu: Barbel Srug, Single Dumbel Srug, Upright Row, Dumble Lateral, Dumble Front Raise, Lateral Raise, shoulder Srug.

- Latihan perut: Sit Up, V Sit Up, Crunch, Rusian Twist, Back Up, Side Bent Dumble, Plank.

\section{HASIL \& PEMBAHASAN}

Berdasarkan data yang diperolah dari 31 sampel menunjukkan bahwa data untuk lingkar dada, lingkar lengan, dan lingkar paha menunjukkan adanya perubahan baik itu sebelum penerapan WFH ataupun sesudah penerapan WFH.

Tabel 1. Statistik Deskriptif

\begin{tabular}{|c|c|c|c|c|c|c|c|c|c|}
\hline \multirow[b]{2}{*}{ Keterangan } & \multirow[b]{2}{*}{$\mathrm{N}$} & \multicolumn{4}{|c|}{ Pretest } & \multicolumn{4}{|c|}{ Postest } \\
\hline & & Min & Max & Mean & $\begin{array}{c}\text { Standard } \\
\text { Deviation }\end{array}$ & Min & Max & Mean & $\begin{array}{c}\text { Standard } \\
\text { Deviation }\end{array}$ \\
\hline Lingkar Dada & 31 & 42 & 142 & 77.39 & 17.062 & 42 & 152 & 80.16 & 17.915 \\
\hline Lingkar Lengan & 31 & 12 & 59 & 28.13 & 10.623 & 12 & 69 & 29.68 & 10.691 \\
\hline Lingkar Paha & 31 & 28 & 77 & 50.39 & 10.484 & 28 & 87 & 52.33 & 110.71 \\
\hline
\end{tabular}

Dari data hasil pengujian hipotesis terdapat perbedaan rata-rata lingkar dada yang signifikan sebelum dan sesudah penerapan WFH sebesar 77,39 dan 80,16. Untuk data yang lain terdapat perbedaan rata-rata lingkar lengan yang signifikan sebelum dan sesudah penerapan WFH yaitu sebesar 28,13 dan 29,68, kemudian hasil untuk lingkar paha terdapat perbedaan rata-rata sebelum dan sesudah penerapan WFH sebesar 50,39 dan 52,33. Dari data di atas untuk lingkar dada, lingkar lengan, dan lingkar paha mengelami perubahan signifikan sebelum dan sesudah penerapan WFH dikarenakan dengan proses latihan yang rutin dan dengan menaikan intensitas latihan (menaikan repetisi, set dan beban) akan meningkatkan masa otot dada dan itu terlihat dari ukuran lingkarnya. Disimpulkan dari data di atas bahwa penerapan WFH (workout from home) dapat mempengaruhi hipertrofi otot secara signifikan.

\section{SIMPULAN}

Penerapan latihan WFH (Workout From Home) selama masa Pandemi Covid-19 ini yang sudah dilakukan oleh 31 sampel penelitian menunjukkan hasil yang positif dan signifikan untuk semua otot yang dilatih yaitu otot dada, otot lengan, dan otot paha. Dari hasil penelitian ini, juga terdapat kelemahan yaitu tidak bisa terkontrol sepenuhnya dalam melakukan setiap gerakan karena sampel melakukan progam latihan secara mandiri sebagai konsekuensi dari pembatasan karena adanya Pandemi Covid-19. 


\section{DAFTAR PUSTAKA}

Ade R., Hamid, L., \& Halim, T. (2007). Bakar Lemak Tanpa Lapar Tanpa Lemas (3rd ed.). Tabloid Bola.

Afrilia Suryanis. (2020). Olahraga Ringan Dapat Cegah Covid-19 - Ilmu dan Teknologi koran.tempo.co. Koran Tempo.Cm. https://koran.tempo.co/read/ilmu-danteknologi/451299/olahraga-ringan-dapat-cegah-Covid-19?

BBC Indonesia. (2020). Update virus corona: Kurva, data, peta pasien terinfeksi, meninggal, dan sembuh di Indonesia serta dunia - BBC News Indonesia. Www.Bbc.Com/Indonesia. https://www.bbc.com/indonesia/indonesia-51850113

Creswell, J. (2013). Qualitative, quantitative, and mixed methods approaches. In Research design (pp. 1-26). https://doi.org/10.2307/3152153

Dipna Videlia Putsanra. (2020). Tips Olahraga Ringan Saat Physical Distancing dan Work From Home - Tirto.ID. Https://Tirto.Id/. https://tirto.id/tips-olahraga-ringan-saatphysical-distancing-dan-work-from-home-eH2r

Djoko Pekik Irianto. (2000). Dasar-dasar Latihan Kebugaran. Yogyakarta: Andi Offset. Kemenkes. (2020). Situasi Terkini Perkembangan Coronavirus Disease (Covid-19) $20 \mathrm{Mei}$ 2020 » Info Infeksi Emerging Kementerian Kesehatan RI. Https://Covid19.Kemkes.Go.Id/. https://covid19.kemkes.go.id/situasi-infeksiemerging/info-corona-virus/situasi-terkini-perkembangan-coronavirus-disease-Covid19-20-mei-2020/\#.XsZ2TxozY2w

Matthews, M. (2014). Bigger leaner stronger the simple science of building the ultimate male body. In K. W. Published (Ed.), Oculus Publishers, Inc. 2 (2). https://doi.org/10.1017/CBO9781107415324.004

Nurjaya. (2018). "Workout vs Work out”, Apa Sih Bedanya? - Kampung Inggris Pare. Https://Www.Kampunginggris.Id/. https://www.kampunginggris.id/workout-vs-workout

Pratama, A. E. (2012). Pengaruh Latihan Compound Set Terhadap Hypertrophy Otot Pada Members Gmc (Gajah Mada Medical Center) Fitness Centre Effect of Compound Set Exercise on Muscle Hypertrophy of Members of Gmc. Gajah: Jurnal Olahraga UNY. 2. $1-9$.

Realbuzz Team. (2020). Are Home Training Workouts Effective? | realbuzz.com. Https:/Www.Realbuzz.Com/. https://www.realbuzz.com/articlesinterests/fitness/article/are-home-training-workouts-effective/

Steve. (2020). The 7 Best at Home Workouts (No-Equipment Required) | Nerd Fitness. Https:/Www.Nerdfitness.Com/. https://www.nerdfitness.com/blog/the-7-best-athome-workout-routines-the-ultimate-guide-for-training-without-a-gym/

Sugiyono. (2010). Metode Penelitian Kuantitatif, Kualitatif dan RnD. Bandung: Alfabeta.

Sukadiyanto. (2011). Pengantar Teori metodelogi Melatih Fisik. Jakarta: Lubuk Agung.

WHO. (2020). Corona virus disease 2019. https://www.who.int/emergencies/diseases/novelcoronavirus 2019?gclid=EAIaIQobChMIoO7plfTE6QIVUX8rCh2CZgBjEAAYASAAEgIRBvD_ $\mathrm{BwE}$

Yuliana. (2020). Corona virus diseases (Covid -19); Sebuah Tinjauan Literatur. Wellness and Healthy Magazine. https://wellness.journalpress.id/wellness/article/view/v1i218wh. 